\title{
FOLKLORE STUDIES AND PRESENTATIONS \\ OF FOLK SONG TRADITIONS \\ OF SLOVENIAN-FRIULAN BORDER AREA
}

\section{MARJETA PISK}

The paper examines the influence of folklore studies on creating the presentations of the folk song traditions of Slovenian-Friulian border area. Comparative analysis of the collected and published folk songs of this area is extremely difficult because Slovenian and Italian folklore studies have primarily operated as legitimizers of national particularism and searched distinctive features on which to base an independent ethnic identity.

Keywords: folklore studies, nationalism, Slovenian-Friulian border area.
Članek obravnava vplive folkloristike na oblikovanje predstavitev ljudskega pesemskega izrocila slovensko-furlanskega obmejnega področja. Primerjalna analiza zbranih in objavljenih ljudskih pesmi s tega področja je zelo težavna, ker sta slovenska in italijanska folkloristika prvenstveno delovali kot legitimatorki nacionalnega partikularizma in sta se osredinjali na razločevalne elemente, ki bi utemeljevali neodvisno etnično identiteto.

Ključne besede: folkloristika, nacionalizem, slovenskofurlansko obmejno področje.

\section{ETHNICITY AND BORDER AREAS}

Throughout its history, Europe has been divided into numerous political, state, and ecclesiastical units, which have represented a more or less significant line of demarcation between Us and the Other.

The basis of any repertoire in contact with two distinct groups lies in a single, universal criterion: identifying those differences between $U_{s}$ and Them, for which the actors believe that they are of such a nature and so great that, because of them, They as a group will never able to become like Us and Ours. (Šumi 2000: 33)

The borders can be of various types: political, linguistic, historical, geographical, ecclesiastical, religious, and so on. Only rarely do these various types of boundaries coincide, and so it is necessary to investigate where they agree and differ in order to determine their influence and significance (cf. Perusini 1973: 79). Folklore studies can make a significant contribution to identifying these shared characteristics that would otherwise remain hidden (cf. Perusini 1959: 157).

From the $19^{\text {th }}$ century onwards, scholarly attention especially focused on the boundaries between ethnic groups because ethnicity had become the chief differentiating quality. The construction of ethnicity is based on "a perceived repertoire of cultural differences that 
become so socially important that people see them as impassable, and the manipulation with this repertoire" (Šumi 2000: 33). Ethnicity can be therefore understood as people's conceptualization and behavior related to cultural difference; specifically, those differences that a person sees as based on impassable and insurmountable causes and origins. "They are such because they are seen as having existed forever" - they are therefore original and they cannot be leveled, done away with, or invalidated. This projection in time, "forever," is critically important for the production of ethnicity. ...The temporal dimension is essentially what the ethnic obstacle is constructed from. (Šumi 2000: 42)

Ethnicity thus becomes a model of social organization only when two or more groups or communities are mutually aware of each other as adversaries, and it therefore depends on social contacts and cultural oppositions (Minnich 1994: 277).

The presentation of an ethnic identity is, therefore, a process of making distinctions that are not only ethnographic but also politically desirable. Ethnic formations are constructed in a process that can be called the ethnicization of culture. In this interpretative and argumentative process, cultures and local specificities come to be viewed as distinct through 'an ethnicizing gaze' that makes the observed distinctions 'ethnically' relevant. (Anttonen 2005: 86-87)

In a border area, the influence and significance of ethnicity started to be more clearly expressed in institutional frameworks in the $19^{\text {th }}$ century, which also had a certain influence on shaping the representation of popular traditions in these areas. This paper examines the influence of a boundary between Slovenian and Friulian ethnic group on creating of a canon of folk songs of this area, focusing on the area of Goriška brda (Gorizia Hills).

The area known today as the Goriška brda (or simply Brda) has very often been a border area. As far back as AD 1000, the Goriška brda became a border area between the domains of feudal lords. These primarily involved the Patriarchate of Aquileia and the Counts of Gorizia, and the Goriška brda fell into the estates of the latter. After the decline of the Counts of Gorizia in 1500, this area became a border region between the Habsburg domains and the Venetian Republic, and after 1866 between the Kingdom of Italy and the Austro-Hungarian Empire (cf. Marušič 1999: 117, 123). After the First World War, under the Treaty of Rapallo of 12 November 1920, which defined the state border between the Kingdom of Italy and the Kingdom of the Serbs, Croats, and Slovenes (i.e., Yugoslavia), the Goriška brda were assigned to Italy and the state border shifted away from the Goriška brda to the east (Marušič 1999: 124). The border between Italy and communist Yugoslavia, defined after the Second World War, again ran through the Goriška brda, but like the previous border it was not delineated on an ethnic principle because in its southeastern parts Italy received completely Slovenian settlements and villages (Marušič 1999: 127). This border also remained unchanged 
after Slovenia became an independent country. Since the implementation of the expanded Schengen agreement on 21 December 2007, border controls are no longer carried out at the crossings between Italy and Slovenia. Slovenians represent the majority of the native population in this area on the Slovenian side of the border, and Friulians represent the majority on the Italian side. These two groups lived in peaceful coexistence and cooperation for many centuries, primarily within the same states - however, at the same time, there are distinct cultural and linguistic differences between them. This makes it possible to study affinities and differences in their folk-song heritages. The question is whether affinities, interconnections, and interference predominate in the folk heritage of ethnic groups living in the same geographical area, or whether differential elements prevail.

\section{FOLK SONG HERITAGE OF THE SLOVENIAN-FRIULIAN BORDER AREA}

Although folk music is a cultural universal, it is not an activity that is universally understandable to everyone. Namely, each music is embedded in its environment: regional, local, ethnic, national, social, and so on.

Folk music has always been embedded in its local environment, although certain melodies and motifs have also traveled exceptional distances and have relatively quickly and effectively migrated from one end of the continent to the other. ... Folk music is therefore essentially situational, embedded in an environment of direct and indirect use; it is local, and therefore it differs by region and is locally effective, and it is continuously changing and has a vital unpredictability. (Muršič 2002: 25)

Therefore, if musical analysis is to be used to define the differences between Friulian and Slovenian folk song in a border area in the traditional analytical manner of the folkloristic research,

tonal criteria must be disregarded because, like most of Slovenia, Friuli belongs to central European alpine musical culture, which is quite homogenous among all of the ethnic groups in the Alps. Differences in the folk melodies of individual ethnic groups can easily be heard, but require a large number of microanalyses to be determined in a concretely analytical manner. (Vodušek 2003: 91)

The source of the alpine character of Slovenian folk music may be sought both in the millennium of Germanic influence and in the indigenous, probably Celtic, substrate (cf. Vodušek 2003: 91). If, in general, the differences between Slovenian and Friulian folk music are not unambiguously definable, these are quickly identifiable in the lyrics of folk songs from this area, because these are in either Slovenian or Friulian language. Despite the close coexistence of both ethnic groups and the not insignificant proportion of mixed 
marriages ${ }^{1}$, we can find only few "bilingual" or "macaronic" songs in which the languages mix or in which there is noticeable linguistic interference. ${ }^{2}$ On the other hand there are more records of the "macaronic" songs mixing Slovenian and Italian languages, especially love songs and lullabies. ${ }^{3}$

The vernacular form of the dialect, which sometimes mixes Slovenian, Friulian, and Italian dialect vocabulary, can especially be identified in the locally colored mocking and teasing songs, as well as certain love songs that are localized to this area, such as "Šel sem v Gorico" (I Went to Gorizia) $\left(\mathrm{GNI}^{4^{*}} \mathrm{R} 25.500\right)$ :

Jast sam šu u Garicu, su la piazza verde, jast sam mev marožu, con tre cento serve...
I went to Gorizia,

I went to the green square,

I had a lover

With three hundred servant girls...

Linguistic interference is not found or is very rare in other Slovenian songs collected in this area; similarly, Friulian-Slovenian linguistic mixing is not found in printed collections of Friulian folk songs. A comparative analysis of the lyrics of folk songs in both traditions does not reveal any explicit relatedness of motifs or themes that go beyond the framework of what is archetypal. However, this absence of an explicitly common element does not indicate the absence of cultural contacts or joining of folk cultures. ${ }^{5}$ For example, Franc Mavrič's notes from 1912 accompanying the transcription of the song "Moj fantič tam s spodnjega kraja, mi druge dekleta napaja" (My Boy That Lives Down There is Courting Other Girls) (GNI O 9181) state that "for dances in the Goriška brda they set up berjarje or brjarje, which are open-air dance floors. There are many such dance floors in Friuli. For dance events, they usually bring berjarje from Mossa/Moš, Lucinoco/Ločnik, San Lorenzo/

1 Eg. in Goriška brda: mainly between Friulian or Italian men and Slovenian women from Brda. Much more exceptional were marriages between Friulian or Italian women and Slovenian men from Brda.

2 This is found, for example, in a carol that children sang at bonfires on Epiphany:

An ti sveti trje kraji

an to svieto nuovo lieto

Bub nan dej no duobro leto,

use gracie ti-na ten svetu in kla-na tien.

Bon vin, bon pan, bujne sope, dolíe vin. Eeeee. .

(Platischis/Plestišča, 13 Aug. 1968, in: Merkù 1976:327-328)
Both the Feast of Epiphany,

And Blessed New Year's day,

May God grant us a good year,

All favors in this world and beyond.

Good wine, good bread, rich soup, sweet wine. Eeeee...

3 Bonfires on the evening before Epiphany, which are widespread in Friuli, are known in Slovenia only in the extreme western part of the country, in the Goriška brda (Kuret 1989: 476), which border on Friuli. A Friulian influence is also apparent in the term used for caroling in the Goriška brda; that is, šjop, as in smo šli v šjop ('we went caroling'), from Friulian siop ('gift for Christmas or Epiphany').

4 Archive of the Ethnomusicological Institute SRC SASA (Glasbenonarodopisni inšstitut - GNI ZRC SAZU), Ljubljana.

5 Friulans have adopted Friulan lyrics on the melody of Venetian Slovenian folk song "Oj božime":

Vidulajle, vidulajle, che biele frute,

vidulajle, vidulajle, che biele frute,

vidulajle fin che le timp. (GNI ZRC SAZU, Teren (10 - Goriška Brda, Dr. R. Hrovatin VIII., vol. 3, p. 68). 
Šlovrenc, etc. in Friuli” (GNI ZRC SAZU, OSNP 201, Franc Mavrič from Bovec, note to song). On the other side Friulian designation schiave 'Slav' also indicates Steierisch melodies, which are often found alongside the expression lo stajari 'the Steierisch', indicating that the Friulians borrowed the traditional alpine quatrain from their Slavic neighbors, as the melodies themselves also attest. The Friulian influence on Slovenian tradition can be recognized in the lyric and musical forms of Slovenian songs that repeat the first line in a four-line stanza three times and only add another line at the end; for example:

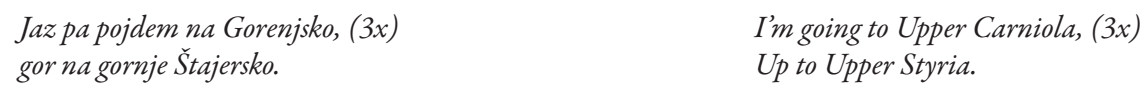

This type of Slovenian song has a metrical pattern of octameter and heptameter couplets, which is unknown in the stratum of older Slovenian songs but is a constant metrical pattern in the Friulian villotta (Vodušek 2003: 92). It is characteristic of the villotta for the first line to repeat three times and for the second line to conclude the melody (Ankündigung 2004: 183). Villotte often contain the same lyric strophic form, which is also expressed musically in the same manner with sequences as in Slovenian songs of this sort. "Friulian influence is therefore not impossible in this case, which is also supported by the fact that this song form is popular among the Venetian Slovenians and it is generally found more often in western Slovenia than in eastern Slovenia” (Vodušek 2003: 92). In the west, refrains are also more frequent, which are relatively rare in Slovenian folk song. Most often the refrain is at the end of the strophe, but it may also be inserted between the lines or may create part of a line (Kumer 1988: 264), similar to a villotta.

\section{FOLK-SONG RESEARCH AS A FACTOR IN ACCENTUATING DIFFERENCES}

One difficulty in comparative research on Slovenian and Friulian folk heritage lies in the different orientations of researchers investigating Slovenian and Friulian folk-song traditions. With the exception of the informal Alpes Orientales group of researchers that cultivated comparative research on the ethnologically heterogeneous eastern Alps, which are nonetheless historically, geographically, and culturally connected, and met at conferences from 1956 to 1975 (Baš, ed. 2004: 6), Slovenian and Italian folklore studies have primarily operated as legitimizers of national particularism and the search for distinctive features on which to base an independent ethnic identity.

At the end of the $18^{\text {th }}$ century, at the start of the modern era in Europe and the very beginnings of shaping nations, it was not the music of individuals, but the music of the multitude, that represented national character in the most recognizable form (cf. Bohlman 2004: 10). Folk music and folk song acquired legitimacy as cultural artifacts for the elevated purposes of representing the nation-state (Bohlman 2004: 11) or in the struggles to achieve the nation-state desired. 
One of the few discussions on the traditions of the Slovenian-Friulian area that proceeded from different premises appeared in the popular series Die österreichisch-ungarische Monarchie in Wort und Bild (The Austro-Hungarian Monarchy in Word and Image), which was published in Vienna between 1887 and 1902 at the initiative of Archduke Rudolf, the son of Emperor Franz Joseph I. The Slovenian-Friulian area is discussed in volume, titled Das Küstenland (Görz, Gradiska, Triest und Istrien) - that is, The Littoral (Gorizia, Gradisca, Trieste, and Istria). The description of folk culture in the Gorizia region, included in the section Zur Volkskunde des Küstenlandes (The Folk Culture of the Littoral), is the work of Count Franz Karl Coronini Cromberg, who was the governor of the Princely County of Gorizia and Gradisca for many years, and was loyal to the Habsburg court and the Austrian idea. The last part of his description of folk culture in the Gorizia area focuses on folk song and differences in the songs of three ethnic groups: the Slovenians, Friulians, and Italians (Coronini 1891: 187-190). One of the few comparative descriptions of the song tradition of all three ethnic groups in this area begins with an analysis of singing activities among the Slovenians, who were very skilled at singing and enjoyed singing merry songs:

Ever since the national spirit has strengthened, folk melodies and their lyrics have been diligently collected. Many singing societies (and, where these do not exist, reading societies) have been learning and cultivating singing with great zeal, so that the number of good, solid men's choirs and their harmonious singing exceeds one's expectations. The original character of folk singing has probably suffered a setback, but at the same time it has unarguably acquired greater artistic integrity of its execution, ever since the melodies and lyrics ceased being passed from old to young and from mouth to mouth, and have been fixed in written form with the aid of sheet music and songbooks. At the same time, it can be concluded that, however far away Slovenians live, the same songs are heard everywhere today.

This is followed by a description of Friulian and Italian tradition:

There is no need to specially emphasize that the Friulians and Italians do not sing any less than the Slovenians, because the throats of the Romance peoples are primarily organs of song. Their singing remains completely uncorrupted. Now one hears among them a completely artificial and sentimental song that comes from southern Italy and has made its way to our environs by dint of rapid propagation through oral tradition, and then one hears a popular song of the streets, in which new lyrics have been adapted to an old familiar melody. Songs with explicitly patriotic content arose not long ago ... These Friulian and Italian songs are also making their way into the Slovenian villages that lie on the linguistic border.

The true Friulian folk song (the villotta furlana) exhibits special features. During the sultry summer evenings, the girls gather at the well or headlands at the edges of fields and the boys stand opposite them, and the singing 
alternates between them; their lyrics are often improvised, influenced by and skillfully using the given situation and the persons present. The content of these improvised songs is primarily erotic, but also mixed with teasing songs, to which there is rarely a lack of a sharp response. The sorrow of parted lovers because of military call-up was an especially popular lament. . . Aside from songs with religious content, Friulian folk songs primarily have rough realistic features and often contain bold jests. (Coronini 1891: 187-190)

Coronini attempts to place Slovenian folk-song tradition into the broader context of the South Slavic peoples. In contrast to the Friulian villotte and Italian songs that he later describes, for the Slovenian songs he focuses on the contextual aspect, highlighting the fact that Slovenian folk songs have been diligently collected since the very beginnings of the national awakening. Singing therefore no longer belongs to the domain of nature, as among the Romance peoples, but is a privileged element of culture. Singing in everyday circles and in life is consequently also marked by learned activity that is promoted by the national elites. Coronini reflects on these perceptions and determines that folk song has suffered a loss in original character, although it has gained in artistic value, which conforms with the function that Slovenian national leaders in the Gorizia area assigned to singing. During the time under discussion, and to a large extent afterwards, the promotion of singing was based on efforts to strengthen and consolidate national consciousness because "by teaching Slovenian folk songs . . . , soon trivial Italian songs will disappear from the environs and our Slovenian songs will be heard in their place."6

Other studies of folk-song tradition were subject to the orientations of their national parent disciplines, and so a comparative analysis is often impossible. Specifically, from its very beginnings Slovenian folklore studies followed the German understanding of ballads as legitimizers of national character that demonstrated national identity even before the nation had taken shape (cf. Bohlman 2004: 183), as well as its historical legitimacy. The $18^{\text {th }}$-century philologist Marko Pohlin is believed to have provided the initiative for the first manuscript collection of Slovenian ballads based on an appeal to collect "old songs" in Macpherson's Ossian (1762-1765). Accordingly, a collection by Father Dismas (or Jožef) Zakotnik, containing only five songs, appeared around 1775 (Kumer 1975: 105). Since that time, the history of Slovenian folklore studies has primarily been the history of ballad collection. These ballads treat nation-formation myths to a minor extent; instead, their content is mainly based on everyday family life and on legendary tradition, and they reflect domestic circumstances even when they belong to general European heritage. Foreign countries and the people living in them also do not play as much of a role as might be expected based on historical and sociological conditions. (Kumer 1996: 151)

The orientation of those studying Friulian song tradition was different, although it 
stemmed from similar impulses of ethnic affirmation following the Herderian perspective presupposing a decisive role of folk tradition in the constitution of the nation. Although ballads, religious songs, and other songs in Italian were very widespread in Friuli, research focused on a special form of folk song characteristic of Friuli, called the villota friulana. This song form is typically composed of two couplets, each of which has an octameter line with stress on the penult syllable and a heptameter line with stress on the ultima. Normally only two lines rhyme, accented on the ultima. Considering that people in Italian areas bordering on Friuli (where a Venetian dialect is spoken) can hardly understand Friulian, and that Friuli is bordered on the north by German-speaking territory and on the east by Slovenian-speaking territory, the villotta friulana is unknown in folk tradition outside its native area. The lyrics of villotte are also not believed to have been influenced by the repertoires of northern Italian folk-song heritage (cf. Starec 2005: 70). Namely, the lyrics of the villotte generally have a lyric character (not a narrative one), are usually first person, and often have erotic (including rather explicit sexual allusions) or satirical themes. Every strophe has the form of an independent and interchangeable unit. With few exceptions, there is no fixed connection between the lyrics and melody. Each set of lyrics can be sung (each time combined with other lyrics) to various melodies (Starec 2005: 70).

As a representative of Friulian folk song and culture, villotte were selected and presented as "typically" Friulian, although they represent only a small part of the entire folk-song repertoire of this area (cf. Gri 1988: 184). To a lesser extent, researchers also studied other songs in Friulian that were composed of short lines (pentameter, hexameter, and heptameter lines), religious songs with various metrical forms, children's songs, lullabies, and certain ballads that have a more or less "Friulianized" form (cf. Starec 2005: 71).

Comparative analysis of collected and published material is extremely difficult because both research orientations have primarily isolated the genres that they have conceptualized as typical and representative from the entire song tradition. When creating the representation of Slovenian folk songs from this area (e. g. Merkù 1976; Je žalostna 2007) merely material that constructs Slovenian national character was presented and lyrics in which the influence of neighboring ethnic groups may be recognized were omitted. The stereotypical images that folklore specialists also helped create because of ideological needs are therefore an area that modern studies of folk-song tradition cannot afford to overlook (cf. Gri 1988: 184).

Without questioning the cultural historical value of such collections, or the many possibilities that they offer and open up for historical research, ... it is of utmost importance that the collected materials be viewed as representations created in particular rhetorical contexts, employing particular strategies in the making of the present, and that their nature as such be integrated into both their analysis and the estimation of their political significance. (Anttonen 2005: 81)

It is obvious that

[c]reating collections is not an innocent form of representation. Instead, it is 
$n$ activity pertaining to the politics of culture and history and contributing to the discourses on difference and the political construction of continuities and discontinuities. Collections depoliticize the communication from which 'folklore' as entextualized artifacts is extracted. At the same time these artifacts are transformed into mimetic representations that create their own politics. When conceptualized as collections of items brought back from modernity's otherness, folklore may speak for the politically correct way of constructing local or national heritage. (Anttonen 2005: 52)

\section{FOLK-SONG TRADITION AND NATIONALISMS}

In the second half of the $19^{\text {th }}$ century, when various creative forces were mobilized in central Europe in the affirmation of national communities and demands for nation states, "nationalistically minded folklorists have tended to collect, index and display materials that have received their meanings as nationally significant symbols not from their performers but from the people who collect and display them" (Anttonen 2005: 87).

With its historical background in the legitimization and sacralization of territories with antiquities, and in the related Herderian idea of the nation as being embodied and voiced in traditional culture, especially in the poetry of the folk, folklore scholarship has contributed to nationalist symbolism and metonymy by providing 'ancient testimonies' of history in the national language for the legitimization of the political state as a national unit. By transforming tradition into heritage, and by metonymizing tradition in the course of its representation, folklore scholarship has created 'national texts' that are authored by 'the folk' and speak in the voice of 'the nation'. (Anttonen 2005: 88)

Oral traditions do not become nationally significant and symbolic merely by existing somewhere, but through their transformation (cf. Anttonen 2005: 88) therefore many new songs and arrangements of folk songs were created, especially popular among the common people in the Friulian villages under Austrian control (cf. Starec 2005: 72) which contained patriotic Friulian demands for autonomy. Some of them had also anti-Slavic lyrics: ${ }^{7}$

7 Francesco Spessot, Viloti' furlanis respadis a Fara e lenti intor (Friulian Villotte from Fara and the Surrounding Area), Gorizia 1926 (reprinted in Studi Goriziani, Udine, no date), 49, note 219. The lyrics were transcribed at the beginning of 1906 from informants born between 1840 and 1850. Other anti-Slavic villotte that were widespread in the Gorizia region at the end of the $19^{\text {th }}$ century were published in Pagine Friulane 10 (1897-98), 146 and 11 (1898-99), 8 (cited after Gri 1988: 187). 
Finirà la razza sclava

La crauta e dut al rest

Ma in Friuli la biela lenga

Sarà simpri tal so puest.
The Slavic race will come to an end, Along with their kraut and other things, But in Friuli the beautiful language Will always have its place.

(Gri 1988: 187)

Patriotic songs with a sharp ethnic orientation are also found among Slovenian songs, although extremely nationalist song lyrics have not been found or at least not collected. For example, in the song "Nisem Taljanka" (I'm Not an Italian) a girl asserts:

\section{Jest niesen Taljanka jan tudi ne bon, son zviesta Slovenka, ljubam muoj duom.}

\author{
I'm not an Italian, \\ Nor will I be one, \\ I am a loyal Slovenian, \\ I love my home.
}

(GNI R 25.558)

A precise historical and philological analysis of the folk songs and tales collected at the end of the $19^{\text {th }}$ century and during the $20^{\text {th }}$ century in eastern Friuli reveals a more intense, deep, and entrenched interweaving between written and oral (i.e., "learned" and "folk") than in other parts of Friuli. This intermingling and mixing intensified where the multilingual context was stronger, accelerating the processes of ethnic self-awareness (cf. Gri 1988: 183). But a folk song in oral tradition is, after all, a different entity than the same song in written tradition. Namely, the transfer from oral to written tradition presupposes numerous factors that depend on various concepts regarding the object of music. Numerous historical and scholarly concepts have a shared purpose: to create an authentic representation of folk song, the internal qualities of which agree with the scholarly interpretation of culture (Bohlman 2004: 175-176).

Alongside this, an observation by Josip Tominšek is interesting. In 1911 he wrote the following to the Committee for the Collection of Slovenian Folk Songs, when he was seeking folk-song collectors in the Gorizia region: "A start has been made, but there is a lack of qualified manpower; in addition, the collection of folk songs is not very promising because people sing less than in Carniola and Styria and, in addition, they cling to many songs from elsewhere" (Murko 1929: 42). It would be interesting to know which songs "from elsewhere" were sung by Slovenians along the Friulian border before 1914. To this observation, Matija Murko added that "Everywhere, people exchange their songs much more than we usually think" (ibid: 42).

The issue of nationalism in folk song is primarily a question of the nationalism of the parent discipline of folklore studies, which is often governed by ideological lines of force.

Recent discussions concerning scholarly agency and the politics and poetics of scholarly practices and cultural representation have called attention to other aspects in the political advocacy of folklore. Without necessarily questioning the argumentative or subversive potentiality of folklore representations in 
the aspiration for cultural or political independence by an ethnic group or a stateless nation, scholars have become aware of the processes of cultural homogenization and the suppression of diversity that nation-making processes also have entailed. If folklore speaks for the nation, it speaks for a particular political construct. (Anttonen 2005: 91)

\section{FOLKLORISTIC IS BORN OF NATIONALISM?}

In border regions, folklore studies has mainly collected, documented, and archived the song genres that the discipline itself endowed with a symbolic function and thereby the status of a distinguishing element from the traditions of neighboring ethnic groups. As early as 1928, Raffaele Pettazzoni took issue with folklore specialists that emphasized the patriotic significance of folk tradition that they believed was capable of defining the deepest identity of a people or nation and of expressing what a particular nation had been and was - that is, its national essence. In contrast to these scholars, Pettazzoni emphasized that the folklore of various peoples is related in numerous elements because "folklore is international due to its pre-national origin” (Cavazza 1987, cited in Gri 1988: 188). However, despite Pettazzoni's efforts, folklore studies were established precisely on an emphatic ethnic principle (seen also from often-circulated slogan "Anthropology is born of colonialism, folklore is born of nationalism" (Köngäs-Maranda, cited in Anttonen 2005: 90), which based ethnicity on the foundation of cultural differences. "From a formalist point of view, this approach involves an error in the assumption that 'ethnic features' are in and of themselves a 'quality' of a particular group because this is a reification of phenomena that by their very nature are the effects of processes, and not a quality of the subject." (Šumi 2000: 42)

It is also necessary to take into account that doing research through fieldwork and creating "total" images on the basis of "particular" testimonies by informants is certainly subject to incompleteness because, in addition to questions of memory and personal attitudes and values, this involves a series of ideological influences that inhabitants on both sides of the border were exposed to. Likewise, merely relying on ethnographic areas that do not coincide with today's linguistic borders does not yield satisfactory results because these can only be detailed for an individual ethnographical phenomenon and do not apply to other phenomena. Studies of cultural substrates that could clarify the relatedness of neighboring peoples' folklore heritage on the basis of prehistoric cultural strata are nearly impossible because of limited data about these peoples and their cultures, and comparative analysis can only hint at them without providing any firm evidence. "The awareness of the fact that culture does not always correlate with the nation is therefore regarded as a proof against the premises of Herderian romantic nationalism in modern folklore study" (Anttonen 2005: 88) that has to be taken into account also when studying the folk song's traditions of the Slovenian-Friulian border area. 


\section{REFERENCES AND SOURCES}

Ankündigung

2004 Ankündigung des Werkes "Das Volkslied in Österreich" (Revised reprint). In: Deutsch, Walter and Eva Maria Hois (eds.), Das Volkslied in Österreich. Böhlau: Österreichisches Volksliedwerk.

Anttonen, Pertti J.

2005 Tradition through Modernity. Postmodernism and the Nation-State in Folklore Scholarship. Helsinki: Finnish Literature Society (Studia Fennica. Folkloristica; 15).

Baš, Angelos et al. (eds.)

2004 Slovenski etnološki leksikon [Slovenian Ethnological Lexicon]. Ljubljana: Mladinska knjiga.

Bohlman, Philip V.

2004 The Music of European Nationalism. Cultural Identity and Modern History. Santa Barbara, CA; Denver, CO; Oxford, UK: ABC-CLIO.

Cavazza, Stefano

1987 La folkloristica italiana e il fascismo. Il Comitato Nazionale per le Arti Popolari [Italian Folklore Studies and Fascism. The National Committee for the Popular Arts]. La Ricerca Folklorica 15: 109-122.

Coronini-Cromberg, Franz Karl

1891 Zur Volkskunde des Küstenlandes. In: Die österreichisch-ungarische Monarchie in Wort und Bild. Das Küstenland (Görz, Gradiska, Triest und Istrien). Wien, 161-190.

Gri, Gian Paolo

1988 Tradizioni popolari friulane nel Goriziano. In: Cultura Friulana nel Goriziano. Fonti e studi di storia sociale e religiosa 3. Gorizia: Istituto di Storia Sociale e Religiosa, 177-190.

Je žalostna

2007 »ežalostna, ma je liepa ta pesem.«Ljudsko izročilo v besedi in glasbi ["How Sad but Beautiful That Song Is." Folk Heritage in Lyrics and Melodies]. Gorizia: Kulturni center Lojze Bratuž, 2007.

Kumer, Zmaga

1975 Pesem slovenske dežele. Maribor: Založba Obzorja.

1988 Etnomuzikologija. Razgled po znanosti o ljudski glasbi. Ljubljana: Univerza Edvarda Kardelja. Filozofska fakulteta. Oddelek za muzikologijo.

1996 Vloga, zgradba, slog slovenske ljudske pesmi. Ljubljana: ZRC SAZU.

Kuret, Niko

1989 Praznično leto Slovencev II. Ljubljana: Družina.

Marušič, Branko

1999 Brda in državne meje. In: Briški zbornik 1999. Dobrovo: Občina Brda, 116-131.

Merkù, Pavle

1976 Ljudsko izročilo Slovencev v Italiji - zbrano v letih 1965-1974 [Slovenian Folk Heritage in Italy. Collected from 1965 to 1974]. Trieste: Založništvo tržaškega tiska.

Minnich, Robert Gary

1994 Citizenship and the Politicization of Ethnicity as Aspects of State-Making in Marginal SouthCentral European Communities. Teorija in praksa 31 (3-4): 267-283. 
Murko, Matija

1929 Velika zbirka slovenskih narodnih pesmi z melodijami. Etnolog 3: 5-54.

Muršič, Rajko

2002 Univerzalne vsebine Vodovnikovega pohorskega pesemskega koša na vstopu v 21. stoletje. Etnolog $12(63): 17-27$.

Perusini, Gaetano

1973 Problemi etnologici di una zona di confine. In Kumer, Zmaga (ed.), Rad 18. kongresa saveza folklorista Jugoslavije. Bovec 1971. Ljubljana, 79-83.

Starec, Roberto

2005 Research Methodology and Achievements One Hundred Years Later. Traditiones 31(1): 67-77.

Šumi, Irena

2000 Kultura, etničnost, mejnost. Konstrukcije različnosti v antropološki presoji. Ljubljana: Založba ZRC.

Vodušek, Valens

2003 Slovenska ljudska glasba v stiku s sosednjimi kulturami. In: Terseglav, Marko and Robert Vrčon (eds.), Valens Vodušek. Etnomuzikološki članki in razprave. Ljubljana: Založba ZRC, 88-93.

\section{FOLKLORISTIKA IN PREDSTAVITVE LJUDSKE PESEMSKE TRADICIJE SLOVENSKO-FURLANSKEGA OBMEJNEGA OBMOČJA}

Članek obravnava vlogo folkloristike pri oblikovanju predstavitev ljudske pesemske tradicije slovensko-furlanskega obmejnega področja. Temelj vsakršnega repertoarja v stiku dveh različnih skupin je namreč v identificiranju tistih razlockkov med "nami in "njimi, "za katere akterji menijo, da so take narave in tolikšne, da zaradi njih Oni kot skupina nikoli ne morejo postati "kot Mi« in "naši (Šumi 2000: 33). Od 19. stoletja so bile v središče raziskovanja postavljene predvsem meje med etničnimi skupinami, saj je etničnost postala osrednja razlikovalna lastnost. Območje Goriških brd (Brda) je bilo vse od leta 1000 obmejna pokrajina med različnimi fevdalnimi gospodi in državnimi tvorbami. Sledeč tradicionalnemu analitičnemu raziskovalnemu pristopu razlike med slovensko in furlansko ljudsko glasbo niso enoznačno doloćljive, so pa hitro prepoznavne v besedilih ljudskih pesmih tega področja. Kljub tesnemu sobivanju pripadnikov obeh etničnih skupin in nezanemarljivemu deležu mešanih zakonov, je objavljenih pesmi, v katerih bi se jezika prepletala, le malo. Vernakularno obliko govora, ki prepleta slovenske, furlanske in italijanske narečne besede, je mogoče prepoznati predvsem v lokalno obarvanih posmehuljah in zbadljivkah ter nekaterih ljubezenskih pesmih, ki so lokalizirane $v$ ta prostor.

Furlanska označba "schiave" za melodije štajerišev nakazuje, da so alpske poskočnice Furlanom verjetno posredovali slovanski sosedje, o čemer pričajo tudi iste melodije. Furlanski vpliv na slovensko izrocilo lahko prepoznamo $v$ tekstni in glasbeni obliki tistih slovenskih pesmi, ki $v$ štirivrstični kitici trikrat ponovijo prvi verz in šele na koncu dodajo drugega. Navedeni tip slovenske pesmi ima metrični model distiha osmerca in sedmerca, ki v starejši slovenski pesemski 
plasti ni poznan, je pa stalni metrični model furlanske villotte. V villottah tako najdemo pogosto isto tekstno kitično obliko, ki je izražena tudi glasbeno na enak način s sekvencami kakor $v$ slovenskih pesmih te vrste.

Težava pri primerjalnem raziskovanju slovenske in furlanske ljudske dediščine je v različnih usmeritvah raziskovalcev slovenskega in furlanskega ljudskega pesemskega izročila. Disciplini sta namreć delovali predvsem kot legitimatorici nacionalnega partikularizma in iskanja razločevalnih posebnosti, ki bi utemeljevale etnično samobitnost. Eden redkih primerjalnih opisov pesemskega izročila vseh treh etničnih skupin, živečih na tem področju, je delo grofa Franza Karla CoroninijaCromberga v poljudnoznanstveni seriji Die österreichisch-ungarische Monarchie in Wort und Bild (Avstro-ogrska monarhija v besedi in podobi). Druge raziskave ljudskega pesemskega izročila so bile podvržene usmeritvam nacionalnih matičnih disciplin, zato je primerjalna analiza pogosto nemogoča. Folkloristika je v obmejnih področjih predvsem zbirala, dokumentira in arhivirala pesemske žanre, ki jim je sama podelila simbolno funkcijo in stem status razločevalnega elementa $v$ primerjavi s tradicijo sosednjih etničnih skupnosti.

Marjeta Pisk, Glasbenonarodopisni inštitut ZRC SAZU / Institute of Ethnomusicology SRC SASA, Novi trg 2, 1000 Ljubljana, Slovenia; marjeta.pisk@zrc-sazu.si 